\title{
ZENEI KÉPZÉSÜNKRŐL NEMZETKÖZI KITEKINTÉSBEN
}

\section{Kenesei Éva}

Kaposvári Egyetem, Pedagógiai Kar

\section{Kodály a tanítók képzéséről}

Kodály Zoltán több mint hatvan éves tudományos és irodalmi munkásságát összefoglaló kötetek címe Visszatekintés. De valójában nemcsak vissza. Bónis Ferenc, a kötet szerkesztője bízik abban, hogy „az értő olvasó számára nem csupán múltat idéző történelemkönyv marad, hanem minden alapvető gondolatával a jövőbe mutató előretekintés.” (Bónis, 1982. 526. o.).

A jövőbe mutató előretekintéssel egyetértve emelem ki Kodály Zoltán azon gondolatait, amelyek kifejezetten a tanítóképzésről, a tanítóságról és a vele koherens kapcsolatban lévő általános iskolai zenei nevelésről szólnak. Kezdjük a gondolatsort az 1929-ben megjelent Gyermekkarok címü írásából vett idézettel. „Akinek nem mindegy, mi lesz itt a zenében egykét emberöltő múlva, nem mehet el közömbösen az iskola mellett. (...) Ha belenézünk a tantervekbe, látjuk: alkotóik messze jártak a nevelés görög eszményétől, amely a zenének központi helyet juttatott." (Kodály, 1982. 38. o.).

Ezek a gondolatok azért fontosak, mert ebben az írásban már szinte teljes mivoltában elöttünk voltak a Kodály-koncepció alapkövei: miért, mikor, hol, ki, mit, hogyan tanítson. Miért? A teljes emberi életnek múlhatatlan része a zene. Mikor? A zenei nevelést a legkisebb korban kell elkezdeni, s végigvinni az iskolán. Hol? Az alapok lerakása az óvodában történik. A közönségnevelés színtere az iskola. Ki? Legfontosabb a generációkat fölnevelő vidéki tanító személye. Sürgető a szaktanárképzés reformja. Mit? Csakis értéket. Előbb népzenét, különös tekintettel a magyar népzene ötfokú rétegére, hogy utána a zenei világirodalommal is megismerkedjenek a gyerekek. Hogyan? Naponkénti énekléssel. Előbb saját hangján énekeljen a gyermek, $\mathrm{s}$ ha hangszert is választ, annak tanulása csak ezután következzen. A többszólamú ének hallásfejlesztő ereje, a kórusmunka közönségnevelő mühelye nélkülözhetetlen. Mindez a zenei írás-olvasás készségének elsajátításával, a relatív szolmizáció alkalmazásának segítségével, élményt adón történjen (Szögi, 1994. 18. o.).

Tekintsünk vissza eredeti idézetünk néhány kulcsszavára: a zene központi helyére, a tantervi minimum megvalósítására. Ezek a gondolatok mind a tanítóképzés, mind a közoktatás számára bőven adnak feladatot napjainkban is. Már-már úgy tủnik, hogy a cél, egy ideális állapot, amelyet a tölünk telhető legnagyobb hozzáértéssel, odaadással igyekszünk a lehető legjobban megközelíteni. Ennél többet, a mai közállapotokat figyelve nem hiszem, hogy bárki is reálisan fel tudna vállalni. Kodály maga is úgy nyilatkozott, hogy száz évre szóló feladatot is megfogalmazott. Ezzel szembesülünk többek között az 1947-ben keletkezett „Polgárjogot a müvészetnek Magyarországon!” címü írásában is. „A zenének olyan tantárggyá kell lennie, amely minden embernek kezébe adja a kulcsot a muzsikához. Ez azt jelenti, hogy ne tanítsa a művészeteket az, aki azokat nemcsak, hogy nem érti, de nem is szereti." (Kodály, 1989. 70. o.). Ide jól illik a Bicinia Hungarica címü írás 1937-es részlete. „Az iskolában pár éve nekipezsdült az élet. (...) Tanítóink hitétől és buzgalmától függ. Övék az eddigi eredmény érdeme, hisszük, nem fognak lankadni a legrosszabb viszonyok közt sem, s majd csak kivívják tárgyuk és munkájuk méltóbb megbecsülését” (Kodály, 1982. 65. o.). 
Remélhetjük csak, hogy napjainkban is számíthatunk még tanítóink hitére és buzgalmára, amely mögött már nem sokat várat magára a társadalmi megbecsülés.

Sokszor állt ki Kodály a zene ügye mellett. Így tett 1956-ban is, amikor a „Tanügyi bácsik! Engedjétek énekelni a gyermekeket!” címü tanulmányban többek között szólt a tanítóképzés helyzetéről is. „A tanítóképzőben egyre zsugorítják a zenei tárgyakat. Már pedig ki vezesse a népet a zene felé, ha az egyetlen ember, akitől ez várható, még annyit sem tanul, mint eddig" (Kodály, 1982. 307. o.).

Tudjuk, hogy a tanterv, és annak megvalósítása örök harcot jelent. Szakmai felelősséggel bíró körökben ezért hangoztatják, hogy a tanterven folyamatosan kell dolgozni, akciókutatásokkal igazolni az elhangzó véleményeket, és valóban, mint egy cél elérését, egyre jobban meg kell közelítenie a gyakorlatnak. „A zenei nevelés rendszerében alapvető és döntő láncszem a tanító. Ha a tanító képzett zenész és hivatását szereti, jól megy a munka, a gyermekek szépen énekelnek, szívesen látogatják az órákat, és ami a legfontosabb: ránevelődnek a zene szeretetére. Nem a tantervet kell redukálni - a rossz tanító a redukált tantervet sem tudja teljesíteni - hanem a tanítók szaktudását emelni. (...) Már 1945-ben kimondtuk a Köznevelési Tanácsban, hogy a tanítók egyetemi végzettsége kívánatos." (Kodály, 1989. 101. 106-107. o.).

\section{Kodály a zenei félmúveltség ellen}

A müveltség, a kultúra, a zeneértés Kodály Zoltán számára zenei nevelésének fontos kulcsszavai voltak. Amikor Kodály úgy fogalmaz, hogy a gyermeknek a hatodik és tizedik év között meg kell adni azt az élményt, amelyre építeni lehet a zenei nevelés egész jövőjét, akkor egyértelmü számunkra, hogy különösebb indoklás nélkül mennyire is fontosak a következő gondolatok a tanítók képzésében. „Kora ifjúságában kezdte meg s élete végéig folytatta harcát a zenei félmüveltség ellen.” (Eösze, 2000. 197. o.).

Mindezek mellett Kodály kiemelte, hogy a zeneértéshez komoly munkára, tanulásra van szüksége mindenkinek. „Zenei nevelésünk reformjáról” szólva 1954-ben hangsúlyozta a következő gondolatokat: „Hiába minden, a zeneértést nem lehet a levegővel beszívni anélkül, hogy a zene elemeit meg ne tanulja valaki. Ez pedig hol történhetik? Csakis az általános iskolában. Az általános iskola kötelessége, hogy minden embernek kezébe adja a kulcsot, amivel bejut a zene birodalmába. (...) Az általános iskola akkor éri el célját, ha nemcsak olvasni tanít, hanem a jó és rossz zene közötti különbséget is megérezteti (Kodály, 1982. 286. o.).” Ismét csak azt mondhatjuk, hogy „az igény felkeltése, az ízlés fejlesztése nem képzelhető el ingyen, azaz fáradságos munka nélkül." (Eösze, 2000. 198. o.).

Kodály tulajdonképpen müvelődéspolitikus is volt egyben. „Az új magyar müzene megteremtésén kívül a zenekultúra elterjesztése, színvonalának emelése volt a legfőbb gondja.” (Eősze, 2000. 148. o.) És ne feledjük, hogy „Kodály legfőbb célja a népzenén alapuló, általános és magas színvonalú magyar zenekultúra megteremtése volt.” (Eősze, 2000. 181. o.) Azt vallotta, hogy: „A népzenétől könnyü út visz a nagy klasszikus zenéhez, az úgynevezett könnyüzenétől semmilyen.” (Kodály, 1989. 194. o.).

Sokan egyenesen a „Legyen a zene mindenkié!” cél realitását kérdőjelezik meg. Végül is nézőpont kérdése, a zene ma már mindenkié. Csakhogy milyen zene? A mindenféle zenés happeningek? Kodály más zenét szeretett volna mindenkiévé tenni, szerinte némely müfaj meg sem érdemli a zene nevet (Pajor, 2006. 25. o.). 


\section{A kodályi koncepció egysége a módszertani szabadság mellett}

Eősze László zenetudós kutatási területei között szerepel többek között Kodály életműve (Eösze, 2000). Egyértelmüen elhatárolja egymástól a koncepciót és a módszert, továbbá felhívja figyelmünket arra is, hogyan lehetséges annak a jövőben való továbbgondolása.

„A koncepció az alapelvek rendszere - s ez örök érték. A módszer ennek helytől, időtől, személyektől függő - tehát változó eleme. A koncepció jövőjének biztosítékai: A koncepció alapelvei tekintetében őrizzük meg az egységet, módszertani kérdésekben biztosítsuk a kutatás-kísérletezés szabadságát - egymás nézeteinek kölcsönös tiszteletben tartásával. A megfelelő tanárképzés, mely nélkül nem várható eredmény. A jó tanárnak hármas követelménynek kell megfelelnie Kodály szerint: legyen alapos szakmai tudása, széles körü műveltsége és ihlető egyénisége." (Eősze, 2000. 164. o.)

A jó tanár meghatározottságának utóbbi három kritériumát napjaink kihívásaként is csak hasonlóan kezelhetjük, hiszen egy intézményt tanárai minősítenek. Kodály jelentőségét az elitnevelés és a közönségnevelés összhangjának megvalósításában is kiemeli. „A pedagógus jelentősége [...] abban áll, hogy felismerte az elitnevelés (a szakzenész képzés) és a közönségnevelés teljes különválasztásának, kettészakítottságának egészségtelen voltát, és mindent megtett azért, hogy összhangot teremtsen köztük.” (Eősze, 2000. 173. o.)

Külön szól Kodályról, a kultúráról. Előadásaiban, cikkeiben szinte refrénként tér vissza a schumanni gondolat: „Des Lernens ist kein Ende” (A tanulásnak sosincs vége). Azt vallotta, hogy „kultúrát nem lehet örökölni [...] a kultúra annyi, mint tanulás: megszerezni, színvonalon tartani nehéz, elveszteni könnyü." (Kodály, 1982., 156., 204. o.)

\section{Nemzetközi összehasonlítások}

„A magyarországi zenepedagógia komoly rangot vívott ki magának a nemzetközi zenepedagógiai összehasonlításban. Ezt egyrészt az iskolai énektanítás szervezettségének, önálló elgondolásainak, másrészt az ének-zene tagozatos iskolákban elért eredményeknek, harmadrészt a pályára felkészítő zenei oktatási intézmények professzionalizmusának, igényességének köszönhetjük. Összességében Kodály szellemi, erkölcsi hagyatékának, amely az értékek örzésére irányította a figyelmet.” (Laczó, 2008).

Magyarország tagja a zenei nevelés nemzetközi szervezeteinek, így minden eszközt megragadunk arra, hogy „zenei nagyhatalom” szerepünket a lehető legkonzekvensebben örizzük. Az Európai Uniónak nem az a célja, hogy egy egységes államot hozzon létre, egy egységes nyelvvel, eltüntesse azokat a különbségeket, amelyeket az egyes országok, az egyes nemzetek, az egyes nemzetiségek kultúrája jelent. Sőt éppen ellenkezőleg, a cél az, hogy azt a sokszínűséget, amelyet Európa ma jelent, meg kell őrizni. A nemzetközi fórumokon irigyelnek bennünket, hogy nálunk még él és éltetődik a néphagyomány. Külföldön járva érdemes ellesnünk a ,jó gyakorlatokat”. Érdemes megnézni Koppenhágában milyen intézményt hoztak létre a könnyüzene oktatásának, hogy ne „hangszemetet” gyártsanak a gyerekek, a fiatalok. A ritmikai nevelés sokszínüségében érdemes figyelnünk a skandinávokra. Elsősorban azokban az országokban, ahol lényegesen nagyobb a bevándorlás, a zenei multikulturális nevelés hangsúlyosan jelentkezik. Azonban a művészeti nevelésben mindezek ellenére a legnagyobb kihívást az jelenti, hogy a család, az iskola, a kortársközösség hogyan tud együttmüködni. 
Szinte minden európai országban a 8-10. évfolyamig és heti egy órában van kötelező énekóra az alapképzés iskoláiban, kivéve Spanyolországot és Olaszországot, ahol a kötelező jelleg csupán a negyedik évfolyamig tart. Európában az írásbeliség felől közelítünk a zenéhez is, míg az afrikai iskolában a zene felöl haladnak az az írásbeliség felé. Bizonyos országokban alapvetően az énekhangra épül a tanítás, míg más országokban hangszerre. Az alapelvek megvalósítása országonként más és más módon történik. Az angolok az iskolában hangszert is tanítanak, a finnek nagyobb hangsúlyt fektetnek az együttes muzsikálásra, a hollandok a multikulturális nevelés szempontját helyezik elötérbe, a norvégok a kreativitás fejlesztését tartják fontosnak, a svájciak a korosztályok eltérö zenei képzésére vannak figyelemmel, a svédek is hasonlóan differenciáltan adják meg a zenei nevelésük célját, a horvátok a zenei élethelyzetekben látják annak értelmét (L. Nagy, 2002).

Ha ezeket a kiemeléseket összevetjük a hazai zenei nevelési koncepciónk elemeivel, azt találjuk, hogy szinte valamennyi gondolata megtalálható nálunk. Az viszont már nem egyértelmü, hogy mikor, milyen mértékben kerülnek az ifjúság zenei nevelésének középpontjába. Ezeket az ismereteket alaposan tanulmányozva tulajdonképpen pozitívan termékenyíthetjük meg mindennapi zenei tevékenységünket. Ezen a ponton engedtessék meg nekem, hogy felhívjam a figyelmet néhány szakirodalomra, melyek nagyban segítik tájékozódásunkat a nagyvilág zenei nevelési törekvéseiben. Szönyi Erzsébet (1988) felhívja a figyelmünket arra, hogy zenei nevelésünket mára inkább a változás és a sokféleség, mintsem az állandóság jellemzi. Továbbra is fennáll a nagy kérdés: mi lehet a zenei nevelés feladata? Ahány módszer, annyi felelet. Kodály mellett hét külföldi zenepedagógiai módszert ismertet meg velünk, további zenei kísérletekre is ráirányítva figyelmünket. Hegyi István (1996) 76 Európán túli, valamint 26 európai ország zeneoktatásáról, zeneoktatási rendszerérôl ad részletes tájékoztatást. Kiváltképp az egyes országokban alkalmazott zeneoktatási módszerek tekintetében forrásértékü a könyv. Kis Jenőné (1994) könyvével a gyakorlati megvalósítás lehetőségeit mutatja be a hallgatók, és a gyakorló pedagógusok számára mintegy félszáz külföldi és hasonló mennyiségü hazai szakirodalom megismertetésén keresztül. A könyv nemcsak újdonságot jelent, hanem az elmélyült szakmai munkát végzők, és a folyamatosan megújulást igénylök táborát is növeli.

Gonda János is fontosnak tartja a Magyarországon kevésbé elterjedt külföldi irányzatok hazai népszerüsítését, s ugyanilyen fontosnak tartja a jelentősebb magyar törekvések külfölddel való megismertetését. A Nemzetközi Kreatív Zenepedagógiai Intézet - Tatabánya - programjaiban minden szerepelt, ami összefügg az általános müvészetoktatás, elsősorban a zenepedagógia kreatív, alternatív törekvéseivel és irányzataival. A napjainkban megfigyelhető sokirányú pedagógiai progresszivitás mögött általában közös a szándék, a vezéreszme, amely röviden így foglalható össze: kreativitás - nyitottság - tolerancia - komplexitás (Gonda, 1996). Többek között 1994. április 7-9. között is megrendezésre került egy Nemzetközi Alternatív Zenepedagógiai Konferencia, ahol Willems módszerét Jacques Chapuis, JaquesDalcroze módszerét Marie-Laure Bachmann, Orff módszerét Manuela Widmer ismertette, továbbá Phil Ellis Kreativitás zenében címmel osztotta meg gondolatait. Az előadások nyomtatásban a Parlando hasábjain jelentek meg (Chapuis, 1994; Bachmann, 1994.; Widmer, 1994.; Ellis, 1994). 


\section{A magyar zenepedagógia példája}

Minden zenei neveléssel kapcsolatos „,világkonferencián” alkalmunk van megismerni azokat a kutatásokat, gyakorlati megvalósításokat, amelyek foglalkoztatják, meghatározzák a zene ügyét. A malajziai Kuala Lumpurban megrendezett XXVII. ISME Konferencia - 2006. július 16-22. - témái egyértelműen igazolják a zene egyetemes erejét, amelyre az egyes országokban, a zenei nevelésben szükséges építeni. A magyar zenepedagógia megmaradt eredményei még mindig például szolgálhatnak a világ számára igényesség, színvonal és értékpreferencia tekintetében (Laczó, 2006. 4. o.).

A 2007-es kettős Kodály-évfordulóhoz kapcsolódva több nemzetközi fórum is lehetőséget biztosított a zenei nevelés áttekintésére. Ennek egyik kiemelkedő rendezvénye volt a 2007. március 19-21. között megrendezett Nemzetközi Kodály Konferencia. A külföldi előadók sorában az első előadó Gilbert De Greeve, a Nemzetközi Kodály Társaság elnöke azt hangsúlyozta, hogy a jelenlegi helyzet nem az, amit Kodály akart. Gyengült, vesztett erejéből a gyermekek ízlésének fejlesztése; a képzés alapossága kívánni valót hagy maga után, és nem is elegendő; a zene mindennapos élvezete, a zenei általánosok világa csak szükebb körben érvényesülhet. Nagyon komoly éleslátásra és tettekre van szükség ahhoz, hogy a zenei müveltség eszközei az iskolán keresztül a lehető legszélesebb rétegek számára könnyen hozzáférhetőek legyenek.

Betsy McLaughlin Moll a pittsburghi Dusquesne Egyetem professzora kiemeli, hogy az egész világ Magyarország felé néz útmutatásért, amely ország még ma is a zeneoktatás fedezete. René Ferrel a Californiai Egyetem (Bakersfield) professzora zenei nevelésünk személyiséget fejlesztő vonásaira, a személyes élmény befolyásoló jelentőségére hívta fel a figyelmet. Lois Choksy Kanada, a Calgary Egyetem tanára legfontosabb üzenetnek tekinti, hogy „csak a legjobb” zenét szabad a tanításban használni. Észak-Amerikában, ahol a kultúrát áthatja a könnyüzene a filmzenétől a rockzenéig, a legkevésbé veszik ezt figyelembe. Az alsófokú zeneoktatás meglehetősen problematikus Amerikában, mivel az iskolák egyáltalán nem kínálnak zenetanulási lehetőséget. Vannak ugyan jó, iskola melletti zenei programok, és néhány iskolában van zenei oktatás is, de általánosságban az amerikai gyerekek meglehetősen egyenetlen zenei oktatásban részesülnek. Miyako Furiya, a Japán Miyagi Egyetem professzora a zenével való toleranciára, más kultúrák megértésére való nevelést emeli ki, azaz a különböző nemzetek identitásának jobb megértését, amely egyben jövőnk záloga is. Németországban a zenei nevelés nem egységes tantervek szerint történik, Matthias Funkhauser (München) különös jelentőséget tulajdonít egy a Kodály-módszer alapján történő összefoglaló zenei tevékenységnek. Dieter Nagel kölni zeneigazgató több évtizedes tapasztalatai alapján is Kodály pedagógiai célkitüzéseinek megvalósításával megújuló német zeneoktatásról szólt (Márkusné, 2007).

\section{A tudományos eredmények realizálódása a gyakorlatban}

Mindezek ellenére sem lehetünk nyugodtak. Szembesülnünk kell azzal a ténnyel is, hogy több fejlett országban komolyan befektetnek az oktatásba, támogatják a kutatásokat. Valamint az is egyértelmủen bebizonyosodott, hogy csak több tudományág összefogásával valósulhatnak meg érdemi kutatások, majd leszürve a konzekvenciákat, az eredmények a gyakorlatban is realizálódhatnak. Erre figyelmeztet bennünket Laczó Zoltán is egy tanulmányában: „Sem a 
reális helyzetfelmérés, helyzetelemzés, sem a nagyon sürgető közeli jövőbeli stratégiák kialakítása nem nélkülözheti társtudományok bevonását, közremüködését (általános és alkalmazott pedagógia, [zene]pszichológia, fejlődéslélektan, szociálpszichológia, szociológia, zenetudomány [zene]esztétika, informatika). Ha a kérdésekre sok szempontú közelítés után adjuk meg a választ, bizonyos, hogy változtatni kell tantárgystruktúrán, tananyagon, pedagógiai és zenei tevékenységeken, a hatásgyakorlás módján. Újra kell értelmeznünk a zenét. Számba kell venni, hogy a zenének milyen funkciói vannak. Nem biztos, hogy feltétlenül csak megismerést biztosító. Szórakoztató is! Relaxáló is. Preventív is. Terápiás is. Kommunikatív, intermediáló is! Erre mind rámutathatna netán a zenei nevelés?” (Laczó, 2001. 450. o.)

Nézzünk mindjárt néhány vizsgálatot az egyik társtudomány, a zenepszichológia kutatási területéről! A zenepszichológia azon eredményeit is jól tudnánk hasznosítani, amelyek a zenei preferenciákat és a zenei ízlést vizsgálják. Klaus-Ernst Behne tanulmányában többek között felhívja a figyelmünket a téma szempontjából is fontos tényre, miszerint a 810. életévig sok esetben éppenséggel a szülö (adott esetben a tanár) a mintaszemély, tehát így a gyerekek a zenei ízlésükben is feléjük orientálódnak. A pubertáskorban kifelé, a hasonló korúak irányában orientálódnak a fiatalok. Kevés zenei stílusirányzatra fókuszálnak, a többi zenét elutasítják, majd az ezt követő években az egyre toleránsabb magatartással fejlődik egyéni ízlésük. Tehát hallgatóink éppen ebben a második ,élet-évtized”-ben vannak, ahol az egyéni zenei ízlés csúcspontja kezdődik (Behne, 1994). Tehát kétszeresen is nagy a felelősségünk, hiszen maguknak a hallgatóknak az egyéni ízlését is befolyásolnunk kell, de ugyanakkor figyelnünk kell arra a tényre, hogy ők lesznek a kisgyermekek számára az egyik ha nem az egyetlen - követendö minta.

Egyre több szó esik hazai vonatkozásban is arról, hogy mi az, ami még a zenei nevelésből megmaradhat nekünk? Többen vallják azt, hogy ez ma már csak a zenei élményátadás lehet. A zenei élménnyel kapcsolatos kutatásról olvashatunk Alf Gabrielsson (Uppsala) tanulmányában, amelyben a vizsgálati személyeknek le kellett írniuk legintenzívebb zenei élményüket, válaszolniuk kellett az erre irányuló kérdésekre. Az élményt kiváltó zenék a legkülönbözőbb müfajokhoz tartoztak, teljes mértékben egyediek voltak. Az eredmények azt mutatták, hogy az intenzív zenei élménynek sok összetevője van és összetett függő helyzetben van a zenétől, a személyiségtől és a szituációtól (Gabrielsson, 1995). Ha valóban emellett kötelezzük el magunkat, akkor legalább erre a három összetevőre a képzésben is különös gondot kell fordítanunk.

Számunkra, magyar zenei neveléssel foglalkozó szakemberek számára, többször is felmerül a kérdés: komolyzene és/vagy könnyüzene? Nehéz meghúzni a határt komoly- és könnyüzene között. A zenei problémák megoldását elötérbe helyező komolyzenei hagyománnyal szemben a könnyüzenét nem nehéz elmarasztalni, ugyanis egyszerübb és konzervatívabb a komolyzenénél. A könnyüzene tonális és ritmikai értelemben is körülbelül ott tart, ahol a komolyzenei hagyomány jó két-háromszáz évvel ezelőtt. Stachó László szerint éppen ezért a legnagyobb tévedések egyike modernnek tekinteni a könnyüzenét, miközben a komolyzenét klasszikusnak nevezik, hiszen a könnyüzene sokkal klasszikusabb. A könnyüzene nemcsak azért könnyebb, mert kevesebb zenei problémát vet föl, hanem azért is, mert kevesebb asszociációs lehetőséget nyújt a komolyzenénél (Stachó, 2007). 
Ugyanerről a kérdésről olvashatunk egy más megvilágításban, a könnyüzene oldaláról Robert Walser tollából. Tanulmányában szeretné tisztázni, hogy mit is ért „klasszikus”, illetve „komolyzene” alatt, és miféle tekintélyt, milyen szemiotikai jelentőséget tulajdonít neki. A komolyzene presztízsének oka transzcendens aurája és az, hogy hatalommal rendelkező csoportok szimbolikus tulajdona. Bár mindkettő azzal a széles körben elterjedt elképzeléssel függ össze, hogy ez a muzsika időtlen és univerzális, tudjuk, hogy a „komolyzene” mint kategória valójában igen fiatal konstrukció. A klasszikus hagyomány „nagy műveinek” mai kánonja a 19. század elején kezdett kialakulni, „régi” szerzők (Bach és Mozart) újrafelfedezésével és szerzői életmüvek publikálásával. Akkor mégis miért használják fel az együttesek a klasszikus zenét? Az egyik legfontosabb ok kétségkívül a presztízs, a másik a szemiotikai lehetőségek. Folyamatosan újrahasznosítják a legkülönfélébb zenei diskurzusokat, és a tömegmédiának köszönhetően ma már lehetetlen tökéletesen szétválasztani a „magas” és „alacsony” kultúrát. Mert így működik a populáris kultúra: az innovációtól és ellenállástól, a jelek és tekintély újbóli megszilárdulásáig vezet az út. Egyszer talán a komolyzenét is átalakítják, és segítségükkel jobban megértjük, hogyan mosódik el a populáris zenészek kulturális munkája révén a klasszikus és populáris közti határvonal, és bomlik fel az a kettősség, amely a 20. század zenei életének meghatározó eleme volt (Walser, 2005).

\section{A kulturális élet új egysége}

Nicolaus Harnoncourt az újfajta régizene-játszás egyik elindítója, és máig talán egyik legnagyobb alakja a „Zeneértés és zenészképzés” című előadásában szintén érinti ezt a témát. „A mai helyzetet szemlélve rögtön feltünik, hogy a zene meghasadt: különbséget teszünk népzene, szórakoztató zene és komolyzene között. Az egyes kategóriákon belül megtalálhatók az egység darabjai - a zene és az élet, illetve a zene mint egész egysége azonban elveszett. [...] Azt hiszem - írja -, ha sikerülne a sokféle zenei stílus nyelvét, jobban mondva sokféle nyelvét a zenészeknek újra megtanítani, s elérni, hogy a hallgatók is ugyanígy értsék ezeket a nyelveket, akkor [...] a kulturális élet újra egy egységbe olvadna össze. Ezt kellene a mai kor zenészképzésének célul kitüznie." (Harnoncourt, 1988. 19., 27. o.).

Magyarországot sem hagyja érintetlenül a globalizáció. Erről szólt Laczó Zoltán is a Liszt Ferenc Zenemüvészeti Egyetem docense 2002-ben Bergenben azon a 25. ISME konferencián, ahol a norvég szakemberek arról beszéltek, hogy felismerték, a müvészeti nevelésre egyre nagyobb szükség van korunkban. Ezért a tanítóképzés óratervében a müvészeti nevelés tárgyait legalább 30\%-ban szerepeltetik. (Hazánkban, a zenében ez csak az ének-zene müveltségi területen tanuló hallgatók képzésében valósul meg.) Ezzel azt kívánják elérni, hogy maguk a pedagógusjelöltek ismerjék fel a müvészeti nevelés fontosságát, tudják módszertanilag is kezelni a müvészeti nevelés anyagát, hogy azután ennek szükségessége bennük meggyőződéssé válva képezze a pedagógiai tolmácsolás részét a napi pedagógiai gyakorlatban (Laczó, 2002a; 2002b). Ezt 2004-ben személyesen is megtapasztaltam Norvégiában a voldai Erasmus partnerintézményünknél tett látogatásom során. 


\section{Irodalom}

Bachmann, M. L. (1994): Jaques-Dalcroze módszere. Parlando, 36. 4. sz. 8-12.

Behne, K. E. (1994): Zenei preferenciák és zenei ízlés. Musik-psychologie, Hrsg von Bruhn, Oerter, Rösing, Rowohlts Enzyklopädie, 339-350. letöltés helye: www. lfze.hu/letoltes/okt_anyagok/laczo/muv_pszicho/Zenei\%20prefer\%20Zenei\%20izles.doc letöltés ideje: 2008. február 04.

Bónis Ferenc (1982): Szerkesztői visszatekintés. In: Kodály Zoltán: Visszatekintés Összegyüjtött írások, beszédek, nyilatkozatok II. kötet. Zenemükiadó, Budapest. 524-526.

Chapuis, J. (1994): Zenei nevelés Willems-módszerrel. Parlando, 36. 4. sz. 3-7.

Ellis, P. (1994): Kreativitás a zenében, avagy az új technika szerepe. Parlando, 36. 4. sz. 26-30.

Eősze László (2000): Örökségünk Kodály. Válogatott tanulmányok. Osiris Kiadó, Budapest.

Gabrielsson, Alf (1995): The study of music experience in music psychology. In: Manturzewska, M., Miklaszewski, K., Białkowski, A. and Burke, R. (eds.): Psychology of Music Today. Fryderyk Chopin Academy of Music, Warsaw. 85-90. letöltés helye: www.lfze.hu/letoltes/okt_anyagok/laczo/muv_pszicho/ALFGABRL.doc letöltés ideje: 2008. február 04.

Gonda János (1996): A zenei nevelés alternatív mühelye. Iskolakultúra, 6. 12. sz. 13-18.

Harnoncourt, N. (1988): A beszédszerü zene. Utak egy új zeneértés felé. Editio Musica, Budapest.

Hegyi István (1996): Világunk zeneoktatási öröksége. A zenetanitás kisenciklopédiája. Janus Pannonius Tudományegyetem, Pécs.

Kis Jenőné (1994): Alternatív lehetőségek a zenepedagógiában. Tárogató Kiadó, Budapest.

Kodály Zoltán (1982): Visszatekintés: Összegyüjtött irások, beszédek, nyilatkozatok I. kötet. Zenemükiadó, Budapest.

Kodály Zoltán (1989): Visszatekintés: Hátrahagyott írások, beszédek, nyilatkozatok III. kötet. Zenemükiadó, Budapest.

Laczó Zoltán (2001): Zenei nevelés a közoktatásban. In: Báthory Zoltán és Falus Iván (szerk.) Tanulmányok a neveléstudomány köréböl. Osiris Kiadó, Budapest. 437-451.

Laczó Zoltán (2002a): A 25. ISME konferenciáról. Bergen (Norvégia), 2002. augusztus 11-16. Parlando, 44. 6. sz. 2-6.

Laczó Zoltán (2002b): A morális nevelés lehetőségei iskolai zenehallgatásban. Parlando, 44. 6. sz. 7-13.

Laczó Zoltán (2006): Kicsit szubjektív beszámoló a XXVII. ISME Konferenciáról. Parlando, 48. 6. sz. $1-4$.

Laczó Zoltán (2008): Zenepedagógia. In: Báthory Zoltán és Falus Iván (szerk.): Online Pedagógiai Lexikon.

letöltés helye: http://human.kando.hu/pedlex/lexicon/Z.xml/zenepedagogia.html letöltés ideje: 2008. február 22.

L. Nagy Katalin (2002): Az ének-zene tantárgy helyzete és fejlesztési feladatai. $U_{j} j$ Pedagógiai Szemle, 52. 11. sz. 73-83.

Márkusné Natter-Nád Katalin (2007): Nemzetközi Kodály Konferencia. 2007. március 19-21. Kodály Zoltán Emlékmúzeum. Parlando, 49. 3. sz. 18-22. 
Pajor Éva (2006): Legyen a zene... de kié? Interjú Szőnyi Erzsébettel. Parlando, 48. 6. sz. 23-25. Stachó László (2007): Zenében rejtett jelentések: bevezetés a zene lélektanába. SZTE ZMK Zeneelmélet Tanszék munkatársának előadása a Mindentudás Egyeteme Szeged. letöltés helye: $\quad$ www.szeged.hu/index2.php?option=content \&task=view\&id=94865\&pop=1\&p letöltés ideje: 2008. február 1.

Szögi Ágnes (1994): „Ez az iskola valaha Kecskemétnek dicsősége lesz”. A kecskeméti énekzenei iskola elsö évtizedei 1950-1973 összefüggésben a korszak müvelödéspolitikai és zenepedagógiai törekvéseivel. Kodály Intézet, Kecskemét.

Szőnyi Erzsébet (1988): Zenei nevelési irányzatok a XX. században. Tankönyvkiadó, Budapest.

Walser, R. (2005): Heavy metal és klasszikus virtuozitás. Replika, 49-50. sz. 211-254.

Widmer, Manuela (1994): Orff-Schulwerk. Az elemi zene- és mozgásnevelés koncepciója. Parlando, 36. 4. sz. 19-25. 